\title{
Locating nature and culture: Pan-Homo culture and theological primatology
}

\begin{tabular}{|c|c|}
\hline \multicolumn{2}{|c|}{$\begin{array}{l}\text { Author: } \\
\text { Nancy R. Howell1,2 }\end{array}$} \\
\hline \multicolumn{2}{|c|}{$\begin{array}{l}\text { Affiliations: } \\
\text { }{ }^{1} \text { Saint Paul School of } \\
\text { Theology, Overland Park, } \\
\text { Kansas, United States }\end{array}$} \\
\hline \multicolumn{2}{|c|}{$\begin{array}{l}{ }^{2} \text { Department of Dogmatics } \\
\text { and Christian Ethics, } \\
\text { University of Pretoria, } \\
\text { South Africa }\end{array}$} \\
\hline \multicolumn{2}{|c|}{$\begin{array}{l}\text { Correspondence to: } \\
\text { Nancy Howell }\end{array}$} \\
\hline \multicolumn{2}{|c|}{$\begin{array}{l}\text { Email: } \\
\text { howellnr@spst.edu }\end{array}$} \\
\hline \multicolumn{2}{|c|}{$\begin{array}{l}\text { Postal address: } \\
4370 \text { West 109th Street, } \\
\text { Suite } 300, \text { Overland Park, } \\
\text { Kansas } 66211-1397, \\
\text { United States }\end{array}$} \\
\hline \multicolumn{2}{|c|}{$\begin{array}{l}\text { Dates: } \\
\text { Received: } 25 \text { Feb. } 2015 \\
\text { Accepted: } 28 \text { June } 2015 \\
\text { Published: } 19 \text { Aug. } 2015\end{array}$} \\
\hline \multicolumn{2}{|c|}{$\begin{array}{l}\text { How to cite this article: } \\
\text { Howell, N.R., 2015, } \\
\text { 'Locating nature and culture: } \\
\text { Pan-Homo culture and } \\
\text { theological primatology', } \\
\text { Verbum et Ecclesia } 36(3) \text {, } \\
\text { Art. \#1440, } 9 \text { pages. } \\
\text { http://dx.doi.org/10.4102/ } \\
\text { ve.v36i3.1440 }\end{array}$} \\
\hline \multicolumn{2}{|c|}{$\begin{array}{l}\text { Note: } \\
\text { This article represents a } \\
\text { theological reflection on the } \\
\text { Faculty Research Theme (FRT) } \\
\text { of the Faculty of Theology, } \\
\text { University of Pretoria, entitled } \\
\text { Ecodomy - Life in its fullness. } \\
\text { The theme is portrayed from } \\
\text { the perspective of various } \\
\text { theological disciplines. A } \\
\text { conference on this theme was } \\
\text { held on } 27-28 \text { October } 2014 . \\
\text { Nancy R. Howell is a Research } \\
\text { Associate of the Department } \\
\text { of Dogmatics and Christian } \\
\text { Ethics, Faculty of Theology, } \\
\text { University of Pretoria, South } \\
\text { Africa. }\end{array}$} \\
\hline \multirow[b]{2}{*}{ 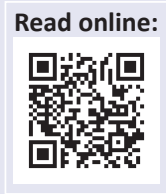 } & \\
\hline & $\begin{array}{l}\text { Scan this QR } \\
\text { code with your } \\
\text { smart phone or } \\
\text { mobile device } \\
\text { to read online. }\end{array}$ \\
\hline
\end{tabular}

Studies of chimpanzee and bonobo social and learning behaviours, as well as diverse explorations of language abilities in primates, suggest that the attribution of 'culture' to primates other than humans is appropriate. The underestimation of primate cultural and cognitive characteristics leads to minimising the evolutionary relationship of humans and other primates. Consequently my claim in this reflection is about the importance of primate studies for the enhancement of Christian thought, with the specific observation that the bifurcation of nature and culture may be an unsustainable feature of any world view, which includes extraordinary status for humans (at least, some humans) as a key presupposition.

Intradisciplinary and/or interdisciplinary implications: The scientific literature concerning primate studies is typically ignored by Christian theology. Reaping the benefits of dialogue between science and religion, Christian thought must engage and respond to the depth of primate language, social, and cultural skills in order to better interpret the relationship of nature and culture.

\section{Introduction}

Concentration keeps me attentive to details, but also makes me selective about what is pushed to margins. Sometimes I regret what I have missed. On a visit to the Iowa Primate Learning Sanctuary a few years ago, I was intensely focused on committee business at hand. My colleague asked me an odd question, 'Did you see a rabbit?' I dismissed the question, knowing that we were indoors and that no rabbits inhabited the premises - only bonobos and dogs. When my meeting ended, two caregivers for the bonobos told me a story. Panbanisha, a female bonobo, particularly gifted with lexigrams and language, had asked for M\&Ms and ice. She was on a diet and realised that she should not have sweets, so she decided (perhaps) that mixing the sweets with ice would dilute the calories. The caregivers then asked her, 'Who would you like to bring you the M\&Ms and ice?' Panbanisha pointed to two lexigrams: gorilla and rabbit. In response, the caregivers, one dressed in a gorilla costume and the other in a rabbit costume, brought the requested foods. For all my concentration on the business at hand, I had missed the most interesting event of the day. A rabbit had actually hopped through the laboratory.

The event with Panbanisha may be anecdotal, but the scenario is not unique. Anderson Cooper visited the bonobos to film for his CNN programme 'Anderson 360' (AC360). Panbanisha and Kanzi, a male bonobo, asked to see his promised surprises in the demonstration of their language ability; Cooper then found himself dressed in the rabbit costume and delivering pine needles, eggs, bread, green beans, and ice. Although embarrassed by his costume, Cooper understood the reason for Panbanisha's request: the video skits used to facilitate learning language when she was young included a character dressed in a rabbit costume. Her memory of the skits lingered in her communication and relationships.

Though not rising to the status of reproducible data, these recollections suggest that humans and animals engage in cultural exchanges involving memory, communication (perhaps even language), imagination, negotiation, and learning. I wonder whether enough anecdotes of this sort might convince humans that non-human animals are not merely social, but cultural beings. Consequently my claim in this reflection is about the importance of primate studies for the enhancement of Christian thought, with the specific observation that the bifurcation of nature and culture may be an unsustainable feature of any world view, which includes extraordinary status for humans (at least, some humans) as a key presupposition.

\section{Method and challenges}

I did not set out to undertake this research; I think I was goaded into the project by a number of scholarly challenges. The first challenger was Stephen Jay Gould, noted Harvard University 
naturalist, whose book Ever Since Darwin: Reflections in Natural History (1977) posed a serious question for theologians and philosophers:

Chimps and gorillas have long been the battleground for our search for uniqueness; for if we could establish an unambiguous distinction-of kind rather than of degree-between ourselves and our closest relatives, we might gain the justification long sought for our cosmic arrogance. The battle shifted long ago from a simple debate about evolution: educated people now accept the evolutionary continuity between humans and apes. But we are so tied to our philosophical and religious heritage that we seek a criterion for strict division between our abilities and those of chimpanzees... Many criteria have been tried, but one by one they have failed. The only honest alternative is to admit the strict continuity in kind between ourselves and chimpanzees. And what do we lose thereby? Only an antiquated concept of the soul to gain a more humble, even exalting vision of our oneness with nature. (Gould 1977:50-51)

'What do we have to lose?' is the question that sticks with me. What real difference does it make that humans and animals might be admitted to be very, very near kin? Shall we humans simply wait until apes have crossed the nature/ culture line, which has functioned as one criterion used not just to separate humans and apes in kind, but sometimes also used to be sure that the distinction in degree is sufficient to keep a safe distance?

The next challengers appeared casually on the front cover of Science magazine in 1999. The cover announced the report of 'Cultures in chimpanzees' (Whiten et al. 1999) first published in Nature and collaboratively authored by a number of scientists noted for their fieldwork in Africa (including, of course, Jane Goodall). ${ }^{1}$ The metastudy systematically compiles observational data from seven regions of Africa with interesting notations of the variations in behaviour among diverse groups of chimpanzees. The kinds of differences range from distinctive forms of tools used to access food, to different styles of vocalisations and grooming. The scientists propose that the distinct behavioural differences point to cultural variation among the chimpanzees, and they define culture as 'any behaviors common to a population that are learned from fellow group members rather than inherited through genes' (Whiten et al. 1999:682).

Obviously the primatologists' definition is not without controversy, and anthropologists are likely critics because cultural anthropology typically reserves the term culture for humans and understands culture to be mediated linguistically. On the other hand, biologists suggest that behaviour moves from generation to generation by means of genetics and social learning - and both have an effect on evolutionary change. As the article in Science (Whiten et al. 1999) explained:

From this perspective, a cultural behavior is one that is transmitted repeatedly through social or observational learning to become a population-level characteristic. By this definition, cultural differences (often known as 'tradition' in ethology) are

1.The issue of Science reported the study in an article by Gretchen Vogel (1999). well-established phenomena in the animal kingdom and are maintained through a variety of social transmission mechanisms. (p. 682)

As if the collaborative article is not bold enough in its claims about chimpanzees, note that the quoted statement indicates that the phenomenon of animal culture or tradition is well established broadly.

The third influence and goad for my research is attention epistemology, a methodological concept described in Sallie McFague's book, The Body of God: An Ecological Theology. Attention epistemology pays attention to a concrete, particular being outside oneself and setting aside oneself: 'Attention epistemology is listening, paying attention to another, the other, in itself, for itself' (McFague 1993:49). Attention epistemology is knowing that requires setting aside vested interest in the instrumental or utilitarian value of the other while engaging in wonder at the instrumental value of the non-human other. McFague (1993) writes:

An attention epistemology is central to embodied knowing and doing, for it takes with utmost seriousness the differences that separate all beings: the individual, unique site from which each is in itself and for itself. Embodiment means paying attention to differences, and we can learn this lesson best perhaps when we gauge our response to a being very unlike ourselves, not only to another human being (who may have a different skin color or sex or economic status), but to a being who is indifferent to us and whose existence we cannot absorb into our own-such as a kestrel (or turtle or tree). If we were to give such a being our attention, we would most probably act differently than we presently do toward it-for from this kind of knowing - attention to the other in its own other, different embodiment-follows a doing appropriate to what and who that being is. (pp. 50-51)

The embodied knowing expressed in attention epistemology requires a decentring of human self for the sake of centring another creature as the focus of observation, wonder, and regard. Such knowing negotiates and interprets embodied difference without diminishing the value of the newly known other and with astonishment at the detail and elegance of its being.

Attention epistemology encourages two directions in my work. First, attention epistemology has challenged me not only to be precise about which species are my focus, but has pushed me to understand the complex intraspecies differences and to remember the names (e.g. Kanzi) of individual non-human animals. ${ }^{2}$ Second, I have become aware of how tempting discovery of behavioural data supporting preconceived notions can be. If one species' behaviour presents an anomaly in relation to religious thought, we can easily move to another species to support an argument. Rather than cede my argument to biological convenience then, I have chosen to focus on chimpanzee

2.See my essay 'Relations between Homo sapiens and Other Animals: Scientific and Religious Arguments' in The Oxford Handbook of Religion and Science (Howell Religious Arguments' in The Oxford Handbook of Religion and Science (Howell
2006). In the essay, I describe the complexity of concepts of similarity and difference between humans and non-human animals. 
and bonobo ethology, learning, and cognition - regardless of whether their behaviour supports my case. The Great Apes are an empirical test of the comprehensiveness, coherence, and integrity of my theological proposals.

\section{Ape culture and nature}

Recently my theological reflection is inspired by Kanzi, a bonobo who is the undisputed celebrity in the PanHomo culture, shaped by multiple forms of language and communication. Terrence Deacon, author of The Symbolic Species, has declared Kanzi to have the most advanced symbolic capabilities demonstrated by any non-human species' (Deacon 1997:124). Deacon's understanding of the term symbol follows Charles Sanders Peirce and connotes 'some social convention, tacit agreement, or explicit code which establishes the relationship that links one thing to another' (Deacon 1997:71). The bonobo-human culture, most recently located in Des Moines, Iowa in the United States, is a generational and longitudinal experiment in language culture, especially involving the use of lexigrams for communication.

Language studies with apes are not new, but the early successful work involved teaching American Sign Language to apes who were cross-fostered with humans. Washoe is a noted chimpanzee, who was born in 1965 and died in 2007. She was part of Allen and Beatrix Gardner's study, which suggested that teaching vocalisations of English to apes made less sense than teaching a gestural language to animals who already communicate with gestures. Fouts and Mills' book, Next of Kin (1997), is an account of his long-standing project with Washoe and a small group of chimpanzees, which continues at the Central Washington University Chimpanzee and Human Communication Institute. Nim Chimpsky, recently remembered in the film Project Nim, was born in 1973 and died in 2000. Herbert S. Terrace of Columbia University led a rather large group of students in the effort to teach Nim American Sign Language (Hess 2008). The gorilla Koko (born in 1971 and still alive) is famous for her empathetic connection with a pet kitten; Koko's language learning occurred with Francine Patterson (Patterson \& Linden 1981). Critics of American Sign Language (ASL) studies are suspicious of the claims that the animals actually understand grammar and syntax, alleging that the human participants must be signalling or over-interpreting the ape signs. At best, the critics are willing to acknowledge that some apes can name objects, but naming is not the same as language ability. Some of the dispute may be related to different levels of understanding of the structure of ASL and to different interpretations of the nature of language and communication.

Not all language studies involve sign language; some studies have used lexigrams as symbolic representations of words. Lana, who was born in 1970, was the first chimpanzee to be part of the language analogue (LANA) project, which investigated language ability in apes. Rather than using gestural language, the project required Lana to use a computer keyboard to select symbols or lexigrams representing English words. She was able to sequence words grammatically and create novel expressions. Important in this work was Duane Rumbaugh's invention of random symbols representing words and the lexigram keyboard, which made communication possible. Lana gained some facility with the keyboard, but her language abilities were limited (primarily to food requests) (Savage-Rumbaugh \& Lewin 1994:48, 183).

The next phase of the research involved Sherman (born 1973) and Austin (born 1974), who also used the LANA keyboard. With Sherman and Austin the focus was peer communication because language is related to sociality. While Lana, the chimpanzee, achieved the ability to make requests, she did not comprehend language, especially when asked to respond to communication from others. Consequently the work with Sherman and Austin concentrated on placing language usage in contexts that facilitated understanding (Savage-Rumbaugh \& Lewin 1994:126). Savage-Rumbaugh writes that the work with Sherman and Austin involved a new approach to ape language research:

Consequently, by focusing on the ability of Sherman and Austin to comprehend symbols, we were forced to develop paradigms in which the execution of the symbol and the ape's receipt of some object or activity associated with that symbol became completely detached. This marked a dramatic break with all other apelanguage efforts, and it led to the apes recognizing that symbols can be used to communicate information about a specific object, event, or whatever without being tied to the occurrence of that event. (Savage-Rumbaugh \& Lewin 1994:126-127)

Ape language studies then advanced to verifiable communication expressing future intentions (SavageRumbaugh \& Lewin 1994:127). Sherman and Austin did not learn to understand spoken English (Savage-Rumbaugh \& Lewin 1994:63, 177). However, they spontaneously developed important aspects of communication - chimp-to-chimp peer communication - using the lexigrams: attending to each other's communications, engaging each other before communicating, gesturing to clarify messages, and taking turns at communication (Savage-Rumbaugh \& Lewin 1994:84). The sociality and cooperation of the chimpanzees increased with more complex usage of language.

The project entered a different phase when bonobos became the centre of attention. Kanzi was born to Lorel, a female bonobo from the San Diego Zoo on 28 October 1980 (SavageRumbaugh \& Lewin 1994:121). Matata, an African born female bonobo, adopted Kanzi on the day he was born (with some plaintive resistance from Lorel) (Savage-Rumbaugh \& Lewin 1994:122).

Matata was part of the language study at the Language Research Centre, but initial work with her was not proving very successful (Savage-Rumbaugh \& Lewin 1994:127). Matata was able to distinguish one lexigram symbol from another, and she could make requests for food, but she could not respond to lexigram communication from others (Savage-Rumbaugh \& Lewin 1994:129). 
Kanzi was an active and playful infant around Matata and was interested in the lexigrams, trying to grab them as they flashed on the keyboard (Savage-Rumbaugh \& Lewin 1994:129). Matata was an indulgent mother with Kanzi (Savage-Rumbaugh \& Lewin 1994:130) and was a patient and interested student, but she did not progress in the systematic training program (as well as Sherman \& Austin had) (Savage-Rumbaugh \& Lewin 1994:130). Yerkes made the decision to separate Kanzi from Matata for a few months while she was sent to breed with Kanzi's father, Bosondjo (Savage-Rumbaugh \& Lewin 1994:132) - and Kanzi was introduced to the language learning programme. Something remarkable happened next:

The day after Matata's departure, we set up the keyboard in the expectation that Kanzi would begin his language instruction-if he could learn to sit in one place long enough. Kanzi, however, had his own opinion about the keyboard and he began at once to make it evident by using it on more than 120 occasions that first day. I was hesitant to believe what I was seeing. Not only was Kanzi using the keyboard as a means of communicating, but he also knew what the symbols meant-in spite of the fact that his mother had never learned them. For example, one of the first things he did that morning was to activate 'apple', then 'chase'. He then picked up an apple, looked at me, and ran away with a play grin on his face. Several times he hit food keys, and when I took him to the refrigerator, he selected those foods he'd indicated on the keyboard. Kanzi was using specific lexigrams to request and name items, and to announce his intention-all important symbol skills that we had not recognized Kanzi possessed. (Savage-Rumbaugh \& Lewin 1994:135)

Kanzi demonstrated for the researchers that enculturation in a language community is key to learning language, which suggests that language training of older chimpanzees and bonobos should be expected to produce less successful language usage and comprehension in apes. Kanzi's language enculturation within the Pan-Homo family resulted in his ability to communicate using lexigrams, but also to comprehend spoken English.

The lexigrams are central to the language learning studies with Lana, Sherman, Austin, Matata, and Kanzi. The lexigrams are not pictures of the objects or actions, but are random geometric symbols. They include nouns, verbs, prepositions, and interrogatives - which are significant grammatical parts of speech for constructing sentences that describe observations, name objects, and make requests. Two interesting aspects of the lexigrams are rather surprising. First, the lexigram keyboard includes written words below the symbols, so that more human persons in the laboratory may use them to communicate. Secondly, the bonobos have developed the ability to recognise the written words, too, and now some words are written rather than having a geometric symbol.

Not all primatologists agree that the best approach to studying language learning and comprehension in apes begins with training apes to use existing or created human language models. Andrew R. Halloran, author of The Song of the Ape: Understanding the Languages of Chimpanzees (2012), is actually a sceptic about ape capacity for human language. Following Herbert Terrace (who attempted language studies with Nim Chimpsky in Project Nim), Halloran claims that gorillas (e.g. Koko) and chimpanzees (e.g. Nim and Washoe) can be trained, but not taught ASL. Unfortunately, the apes fall far short of being able to arrange the signs in any appropriate or understandable order (even though they choose appropriate signs) (Halloran 2012:59).

In spite of Halloran's scepticism about 'training' apes to use human language, he advocates for the study of ape language itself - and offers his 'conversion' experience in an anecdote about ape communication and collaboration. Halloran worked at a Florida animal park, and one day rowed his boat to the chimpanzee island for the purpose of routine cleaning of a building. A small group of chimpanzees who were loyal to Higgy (a deposed alpha male) opportunistically commandeered the boat, which was not secured to the shore. Halloran heard his co-worker screaming, threw down his broom, and walked outside to see Higgy steering the boat with a gondola pole. In the boat were Higgy's last allies: 'the neurologically impaired male named Elgin; an unpredictable and vicious female named Gin; Hank's oversized mother, Cindy; and a very small sixty-eight-year-old female named Little Mama' (Halloran 2014:4). Halloran was/is convinced that the boating excursion was no accident, but a 'planned and orchestrated escape' from the competing new alpha male Hank and his allies (Halloran 2012:7). But, how was the escape plan communicated? Halloran (2012) writes:

The five chimps in Higgy's alliance somehow knew to get on that boat with Higgy at the instant the situation presented itself. The chimps aligned with Hank knew not to get on the boat. (p. 7)

\section{Halloran (2012) further recalls his response to the incident:}

The incident had a profound effect on me. I kept thinking of how planned and orchestrated the escape seemed to be. I began to wonder how this orchestration was communicated..

I was preoccupied with the notion that, perhaps, chimpanzees communicated on a deeper and more complex level than I had ever imagined. Perhaps chimpanzees had their own language; a language which, unlike other forms of animal communication, was learned, differed from population to population, had definitions, had a structure, and conveyed information that didn't necessarily relate to a present time or place. (pp. 7-8)

As a consequence of this experience and observation, Halloran developed a new approach, which eliminated 'training' apes to use human languages and instead examined the vocalisation and communication already present in the apes. Instead of teaching chimpanzees a human language and assessing whether apes can be proficient in the language of another species, Halloran believed the project of ape language studies might best be conducted by looking at how apes already communicate. In other words, human researchers should be learning ape language.

Hence, Halloran's research involves detailed recordings of chimpanzee vocalisations, with an ear to the context and meanings of their communications. His statistical study 
of calls and their correspondence with specific meanings includes the cultural divergence of calls (between Higgy's group, which remained in Florida, and Hank's group, which moved to Lincoln Park Zoo in Chicago). Halloran's (2012) hypothesis is that if:

... chimpanzees learned their own vocalizations, like human language, then it stands to reason that these vocalizations would evolve (like human languages do). The evolution would begin as a slightly different dialect then, eventually, become its own system of vocalizations-a separate chimpanzee language. (p. 234)

Halloran's assumption is based, in part, on earlier research about culture in wild chimpanzees, which demonstrated that chimpanzee communication is not genetically determined, but is a matter of learned group-specific vocalisation (Halloran 2012:186).

Central to debates about what differentiates humans and apes is the discussion of language, so I will take the language issue as an important case that obfuscates the discussion of human uniqueness in evolutionary perspective. The rhetorical character of the discussion lends to the confusions and imprecision of the debate because scholars can sometimes become casual about what constitutes uniqueness, which I understand to be something unparalleled (one of a kind). Clarification of language capacity in humans and apes rests in deciphering what is meant or intended by language - and the discussions range from grammar and syntax to symbolic representation and a wider concept of communication.

Barbara King, author of The Dynamic Dance: Nonvocal Communication in African Great Apes (2004), pushes a broader understanding of communication in African Great Apes in the wild. Using the metaphor of 'dynamic dance', King refers to long-term data on African apes to say that gorilla, chimpanzee, and bonobo communications occur within a socioemotional context-not only social, but more emotionally grounded and related - that facilitates strategic planning for the future, as well as attachment to social partners (King 2004:22). The complexity of communication is that meaning is not merely signalled or symbolised by one individual and then interpreted by another. As King (2004:52) understands communication, meaning emerges by co-regulation rather than in linear transfer of information. King (2004) describes co-regulation:

Co-regulation implies, by its very definition, internally related, nonindependent elements-nonlinearity. When co-regulation is taken into account, we can see that information is not transferred by facial expressions, body movements, gestures, and vocalizations, nor by bits of information that they supposedly carry. These movements (of the face, body, limbs, or vocal tracts) become communicative when the social partners enter into interaction. The social partners are anything but autonomous, because they may transform each other as they act. (p. 52)

Further, King (2004) explains, 'The relevant process in social communication is not transfer, but emergence':

Rather, mutual understanding is something that emerges as both partners converge on some shared feeling, thought, action, intention, etc. Far from following some predetermined format, such a process is intrinsically creative. (p. 52)

As King (2004) broadens an interpretation of communication, her:

main goal in pursuing qualitative research on African Great Apes is to assess whether and when co-regulated social interactions mediated by gesture and body movement result in coordinated social behavior within dyads, families, or social groups. (p. 74)

The central point, for my purposes, is to emphasise that communication (even among humans) is not merely the translation of words and their relationships into meaning, but is a much more complex process than grammar that involves vocalisations, gestures, facial expressions, body position, and nonverbal sounds.

Given Halloran's and King's additions to the discussion of ape language, I return to Kanzi and Panbanisha (his halfsister). Kanzi and Panbanisha are best known for their work with Sue Savage-Rumbaugh, who insightfully discovered that 'training' or teaching apes language using lexigrams is far less successful than enculturating bonobos in a Pan-Homo family fluent in both spoken English and lexigrams (which now include representational geometric symbols for words, as well as spelled words alone or with lexigrams). A less wellknown publication authored by Savage-Rumbaugh, Fields and Spircu (2004) includes an interesting communication experiment to surface non-stereotyped vocalisations.

The protocol began with information communicated by the:

... speaker using a silent keyboard to one of the bonobos or visually by presenting some object. (The silent keyboard is simply a handheld panel containing 348 printed lexical images, and the speaker communicates by pointing at the desired symbol.) The bonobos were located in various separated caging areas, which prevented the receiver of the information from having access to the visual information transmitted to the first bonobo. Once the information was communicated, if the first bonobo did not vocally communicate it to the second bonobo, the first bonobo was asked to do so. A second experimenter, blind to the information, requested the second bonobo to use the keyboard, or in some cases photographs, to translate the vocal information, except in cases when the translation occurred spontaneously. (Savage-Rumbaugh et al. 2004:567)

One simple example of the method:

The caretaker told Kanzi (who was in the first sleeping room) that we're going to have yogurt, by using only the silent keyboard. Kanzi was asked if he would like to announce this to Panbanisha. Kanzi vocalized, then Panbanisha vocalized in return and selected 'yogurt' on the keyboard for the caretaker in front of her cage. (Savage-Rumbaugh et al. 2004:567)

Kanzi and Panbanisha therefore have multiple modes of communication because of their enculturation. In addition to typical bonobo vocalisations, the bonobos use lexigrams and spelled words, understand spoken English, and utter unique non-stereotyped vocalisation to communicate what 
the English and lexigram equivalents say. The experiment shows that:

they can be asked to vocalize to another, as well as the other bonobos at the center and to tell one another specific thingsand they respond by so doing, making it quite clear that their vocalizations are under voluntary control. (Savage-Rumbaugh et al. 2004:567)

Because Kanzi and Panbanisha understand 'human symbolic exchanges' and because they have the 'capacity for modulating their speech to produce human-like words, one would also expect them to utilize their vocal abilities to convey semantic information to one another' (SavageRumbaugh et al. 2004:567). The significance of the vocal translation of English and lexigrams to communicate between bonobos is not a matter of genetic programming (not even of gestures), but is a combination of imitation, learning, and creating novel language attributable to the Pan-Homo culture within which they were reared.

\section{Amazement and wonder(ing)}

Science and Christianity may agree about one thing: the remarkable range of invention and creativity in wild and captive bonobos and chimpanzees is stimulus for amazement and wonder - even wondering. I keep a painting entitled 'Lettuce' in my office to remind me that the artist Kanzi is often more inventive and creative than I.

In addition to Kanzi's accomplishments with language, his ability to communicate and to learn facilitates his participation in the legacy of tool-making common to Great Apes and well known to their fans and researchers. Kanzi, for example, is featured in a YouTube video posted by New Scientist TV ('Best videos of 2012: Bonobo genius makes stone tools'). His accomplishment is making (knapping) and using tools similar to early human stone tools. Both Kanzi and Panbanisha crafted a number of stone tools with different purposes and usually with specific intentions in mind: ranging from entertaining a group of visiting scientists, to Kanzi's clever flaking of a sharp tool for cutting a rope in order to access bananas ('Kanzi the toolmaker'). Language and communication permit transmission of many kinds of learning, and Kanzi and Panbanisha learned knapping, the crafting of stone tools by flaking flint.

Language is not the only cognitive pursuit of chimpanzees. Ayumu is famous for the ability to sequence numbers from one through nine, which does not sound like much of a challenge until the details are evident. From the report 'For Better or Worse, Chimpanzee Minds are Much Like Ours' (Ham 2013), we learn:

Ayumu the chimpanzee didn't hesitate. Shown the numbers one through nine on a computer touch screen, he tapped the numerals in order, even after two through eight had disappeared behind white squares within a fraction of a second. The human audience watching the video of this performance began to murmur as they tried and failed to keep up with the fast-fingered chimp.
'Don't worry, no one can do it', Kyoto University researcher Tetsuro Matsuzawa reassured them with a laugh. 'It's impossible for you'. (n.p.)

In a report to the American Association for the Advancement of Science, an exciting claim emerged: 'New studies of the brainpower of our closest primate cousins reveal how chimpanzee cognition mirrors-and in some cases surpasses-the capabilities of the human brain' (Ham 2013:n.p.). How humbling and exhilarating is this claim. ${ }^{3}$

Remarkable examples of chimpanzee and bonobo accomplishments pepper the scientific literature. Itai Roffman and Eviatar Nevo (2010) summarise a number of Great Ape creative abilities. Among the tools made by the apes are honeybee hive tool kits (see also Fay \& Carroll 1994), termite fishing tools, hammers and anvils (see also Boesch et al. 1994), leaf gloves (see also Sugiyama 1995), and digging tools (see also Hernandez-Aguilar, Moore \& Pickering 2007) (most designed for accessing food). Other innovative and practical items and practices include maps (used to direct apes to tubers), parasite treatments, clubs and spears (see also Pruetz \& Bertolani 2007), leaf 'toilet paper', and twig toothbrushes (see also Goodall 1986 and Fowler \& Sommer 2007). Among more aesthetic and imaginative options, apes create dolls from captured or dead animals or logs (King 2007:57) and dance as in displays especially performed in the rain or at waterfalls. On this latter example, Jane Goodall has wondered about expressions of spirituality and awe in apes who display ritually at the base of a waterfall (Goodall \& Berman 1999:188-189).

\section{For humans and other philosophers}

Without pausing to ask, 'So what?' we may miss the true significance of the Great Ape intervention into the comfortable world of human exceptionalism. To conclude, I will name and briefly explain why I think recent work in primatology should lead to a critical examination of the nature/culture binary and other presuppositions, as well as a reorientation toward so-called 'nature'.

Generally speaking, primate studies increasingly demonstrate awareness of closer and closer links between humans, bonobos, and chimpanzees. Gene mapping is a significant part of the work. Prüfer et al. (2012) published an article entitled 'The Bonobo Genome Compared with the Chimpanzee and Human Genomes'. Mapping the genes of these three species enables not only documentation and comparison of the material gene sequences, but also offers interpretation of the migrations and evolutionary history of the relationships of species. A key conclusion of Prüfer's article is worth quoting:

Here we report the sequencing and assembly of the bonobo genome to study its evolutionary relationship with the chimpanzee and human genomes. We find that more than three

3.To view video of the chimpanzee Ayumu performing the sequencing task, se Chimpanzee cognition: Beats humans at memory tasks, https://www.youtube.com/ watch?v=VPKmcT4IZDk 
percent of the human genome is more closely related to either the bonobo or the chimpanzee than these are to each other. (Prüfer et al. 2012:527)

Derek Wildman (while appointed at Wayne State University) sequenced Kanzi's genome (Wildman et al. 2003; Uddin et al. 2014:2957-2962). Wildman's accomplishment leads to a significant insight: we recognise Kanzi's unique genius in learning human culture, but we also must appreciate that Kanzi is a bonobo who shows us that language and culture are not separate from nature, but are emergent in the natural world. From the genetic research, humans can appreciate the ways that language and culture are part of nature (even our own language and culture), and humans can acknowledge and explore the relationships with and embeddedness of humans in nature and in relationship with our nearest genetic cousins.

A second value in primate studies is discovery of the presence of learning and knowledge transmission in non-human animals, and the promise of understanding how learning occurs in bonobos and humans. One important feature of the research with Kanzi is that we have extraordinary opportunities to discover modes of and capacities for learning in non-human primates. Remember that learning is a critical part of the cultural transmission occurring in the wild with chimpanzees and, therefore, most likely with bonobos. While the research is valuable in and of itself and apart from humans, much of the research on Great Ape capacity for learning language has been instrumental for solving the mystery of how humans learn. Some of the research is directed to theorising about how to assist children with autism to learn.

A third importance is the contribution to our cosmic search for non-human intelligent life. Robert John Russell, the Director of the Center for Theology and the Natural Sciences, has wondered about the nature of extraterrestrial life: whether such life will have moral dilemmas, for example. He predicts that:

the discovery of extraterrestrial life will 'hold a mirror up' to us and we will see someone not unlike ourselves, filled with questions like ours and beckoning to us in hopes of discovering the answers, too. (Russell 2000:66)

Upon hearing and reading his comment, my thoughts were immediately drawn to the SETI (Search for Extraterrestrial Intelligence) project, but also to the tremendous doubt and resistance expressed when some scientists propose the vast presence of 'terrestrial' intelligence and culture in nonhuman species. I suggest that we have not yet fully explored those creatures on Earth who 'hold a mirror up' to humans and have the intellectual capacity to help us see things freshly and understand life more deeply.

A fourth value in primate studies concerns evolution especially interpretation of human evolution and the possibility of exploring 'living fossils'. In his book, Bonobo: The Forgotten Ape, Frans de Waal (De Waal \& Lanting 1997) cites another thinker (see also Zihlman 1984; Zihlman et al. 1978) to suggest an analogy between bonobos and early hominins:

Adrienne Zihlman, an American physical anthropologist, has argued that of all the living apes, the weight distribution of the bonobo is closest to that of the prehistoric African 'ape-men', or Australopithecines. ... [The] bonobo is more like us than like some of the other apes [with regard to weight distribution to the legs as compared with similar weight distribution of arms and legs in other apes]. Zihlman takes this to mean that the human lineage may have evolved from a common ancestor who looked a lot like the long-legged bonobo. (De Waal \& Lanting 1997:25)

As De Waal points out, this cannot mean that humans evolved from bonobos or are more closely related to bonobos, but it may mean that the common ancestor of humans and chimpanzees and bonobos looked much like the bonobo. Roffman and Nevo (2010), in the essay already mentioned, summarise the critical evidence:

Also, we suggest that bonobos, Pan paniscus, based on shared traits with Australopithecus, need to be included in Australopithecine's subgenus, and may even represent livingfossil Australopithecines. Unfolding bonobo and chimpanzee biology highlights our common genetic and cultural evolutionary origins. (p. 1)

Roffman and Nevo are not claiming that humans and chimpanzees evolved from bonobos, but are making the more interesting suggestion that bonobos should be reclassified in relation to an early hominin species, the Australopithecines, which would make clear that we can observe bonobos and by so doing visit a laboratory of evolutionary processes. Roffman and Nevo's (2010) argument depends on the accumulation of comparative evidence and traits:

Bonobos are more slender than chimpanzees, have a tendency for bipedalism, longer legs, longer necks, less body hair, stronger leg muscles, alternating division of body mass, elongated foot bones, and a spine that enters the skull lower than in chimpanzees, all of which are Australopithicus-like traits.

The following gives further examples supporting Pan paniscus as a living Australopithecine: Australopithecus afarensis has a cone-shaped thorax like Pan, with shoulder and back muscles involved in arboreality. These morphological changes are shared between Pan and Australopithecus. Australopithecines express traits of Homo in hand structure (in connecting thumb and fingers for delicate motor skills needed for stone tool-making). (p. 9)

The challenge is to persuade those who prefer for Homorelated species to remain exclusive that such evolutionary and morphological/physiological evidence is conclusive.

For the remainder of the conclusion, the focus of the 'So What?' question is the transformative character of primate studies for philosophers and theists.

The fifth significant insight of primate studies is the pervasive topic in the content of this argument: that the binary of nature and culture is an unsustainable presupposition, given 
the evidence that language and culture are part of nature. The preponderance of my article suggests that the notion that humans exclusively have culture is an ever-weakening claim. The markers of culture are found in chimpanzees and bonobos - and perhaps many other species. Phillip Hefner has written that humans are created co-creators - in other words, are creatures characterised as nature creating culture (Hefner 1993:29, 47). I propose that we open the possibility that some non-human social animals are nature creating culture.

The sixth insight from primate studies is that we must concentrate less on non-human animals as objects and more on the intrinsic value of specific individuals and species. Bonobos and chimpanzees, as well as other nonhuman animals, are beings with more than utilitarian value. They are beings with an understanding of self and relationships. They are creatures with intrinsic value in and for themselves apart from their usefulness to humans. Further implications of the intrinsic value of bonobo and chimpanzee might lead to substantive discussions of the personhood of Great Apes. ${ }^{4}$

The seventh insight concerns the search for a God (or theism) adequate to account for the extraordinary character of many non-human creatures, and I propose that a panentheistic world view accounts best for the kind of God-world relationship that entails sophisticated non-human beings. ${ }^{5}$ In agreement with Sallie McFague, Catherine Keller (2008:52), and Pamela Dickey Young (2002), I contend that the world view most satisfactory to primate studies is panentheistic, which means that God is omnipresent and that the world is God's body (a concept developed also by philosopher Charles Hartshorne) (see Hartshorne 1969, 1978). God's radical immanence could be said to be found in the divine immanence in each creature (understood as a creative agent responding to the influence or lure of God toward rich experience). The struggle for humans is to admit that we are not 'the only child/children of God' in relation to the divine nurturing of and luring toward the noblest and best possibilities for the future. The radical transcendence of God could be said to mean that the depth and breadth of God's being knows no limits and infinitely embraces, engages, and experiences all life everlastingly and immediately.

The eighth insight concerns God's creativity, especially the experience of continuous creation and novelty, which we attribute to God. If I believe in a divine call that beckons humans to experience the rich potential and spiritual depth of the world, then I must as part of a panentheist world view include the belief that God creates continuously not

4.Note that Steven M. Wise has written Rattling the Cage: Toward Legal Rights for Animals (2000). Wise is a lawyer bringing test cases to court in the United States.

5.The panentheism explicit in this essay is indebted to the philosophy of Alfred North Whitehead. As such, Whiteheadian panentheism should not be confused with pantheism (which reduces God to the world). In Whitehead's dipolar theism, God's transcendence is contextualised by the concept of creativity and explicated in the transcendence is contextualised by the concept of creativity and explicated in the
mental pole of divine experience, which Whitehead calls the primordial nature of God (Whitehead 1978:88, 94, 348). only in relation to humans, but also in relation to other creatures. When God's call or in-fluence is actualised, then we experience creative transformation and novelty in the world. I cannot help asking, 'Isn't it possible that the unique experiment in Pan-Homo culture is an instance (or instances) of novelty, the inbreaking of God's creative lure and adventure?'

The ninth significance of primate studies particularly challenges theology to accept 'theological primatology' as a constructive new area of Christian thought. Christianity still requires theological anthropology to sort out the distinctiveness of human existence in relation to God, but theological primatology invites reflection on humans, chimpanzees, bonobos, and other primates. Theological primatology promises to expand Christian understanding of the humans, the world, and God.

Finally, and appropriately so, primate studies lead me to think about the Kingdom of God - or better - the New Creation in crucial ways. ${ }^{6}$ The Kingdom of God is a sound sociopolitical image of the world to come, but I find the concept of the New Creation (New Heaven and New Earth) more compelling. I suggest that the divine future promises a new mode of relationship among humans and with other creatures. In the New Creation, non-human animals are a window to the 'Other'. As we come to know animal Others, we discover that our objectifications and underestimation of them not only limits their well-being and thriving, but also ours. In fact, by sustaining a false notion of animal stereotypes, we exacerbate tensions among humans because our habit of mind is to associate some humans more with animals as a way of dehumanising, objectifying, or villanising them. Slavery, Jim Crow, and alleged genocide in the United States are prime examples. When some humans are, therefore, designated as 'not-quite-human', they experience suffering alongside non-human animals. This is not because of some essentialist or naturalist analogy between dehumanised humans and animals, but because of the practice of human exclusivism (elitism or supremacy) that robs oppressed humans and non-human animals of value and justice. By breaking down binaries, including the nature/culture and animal/human binaries or dualisms, the future promises a new creation in which we value Others as God values them. ${ }^{7}$

\section{Acknowledgements Competing interests}

The author declares that she has no financial or personal relationships which may have inappropriately influenced her in writing this article.

6.My thinking is influenced by David L. Clough's theological reflection on biblical texts about creation, reconciliation, and redemption (Clough 2013).

7.The best case I have seen for this kind of argument is articulated by Kelly Brown Douglas (2005), who suggests that platonised Christianity, exclusivist monotheism, and political power converge to create systemic injustice and oppression in Christianity. A different and equally strong case is developed by Wonhee Anne Joh in Heart of the cross: A postcolonial Christology (2006). 


\section{References}

AC360 n.d., Anderson Cooper entertains Bonobo apes in bunny suit, viewed 28 June 2015, from https://www.youtube.com/watch?v=qsUHuurFLXM

Boesch, C., Marchesi, P., Marchesi, N., Fruth, B. \& Joulian, F., 1994, 'Is nut cracking in wild chimpanzees a cultural behavior?', Journal of Human Evolution 26, 325-338. http://dx.doi.org/10.1006/jhev.1994.1020

Chimpanzee cognition: Beats humans at memory tasks, viewed 28 June 2015, from https://www.youtube.com/watch?v=VPKmcT4IZDk

Clough, D. L., 2013, On animals. Volume 1: Systematic theology, Bloomsbury T\&T Clark, London.

De Waal, F. \& Lanting, F., 1997, Bonobo: The forgotten ape, University of California Press, Berkeley.

Deacon, T.W., 1997, The symbolic species: The co-evolution of language and the brain W.W. Norton \& Company, New York and London.

Douglas, K.B., 2005, What's faith got to do with it? Black bodies/Christian souls, Orbis Books, Maryknoll, NY.

Fay, J.M. \& Carroll, R.W., 1994, 'Chimpanzee tool use for honey and termite extraction in central Africa', American Journal of Primatology 34, 309-317. http://dx.doi. org/10.1002/ajp.1350340403

Fouts, R. \& Mills, S.T., 1997, Next of Kin: My conversations with chimpanzees, Avon Books Inc., New York.

Fowler, A. \& Sommer V., 2007, 'Subsistence technology of Nigerian chimpanzees', International Journal of Primatology 28, 997-1023. http://dx.doi.org/10.1007/ s10764-007-9166-0

Goodall, J., 1986, The chimpanzees at Gombe: Patterns of behavior, Harvard University Press, Cambridge, MA

Goodall, J. \& Berman, P., 1999, Reason for hope: A spiritual journey, Warner Books, New York.

Gould, S.J.G., 1977, Ever since Darwin: Reflections in natural history, W.W. Norton \& Company, New York.

Halloran, A.R., 2012, The song of the ape: Understanding the languages of chimpanzees, St. Martin's Press, New York.

Ham, B., 2013, For better or worse, chimpanzee minds are much like ours, viewed 28 June 2015, from http://www.aaas.org/news/better-and-worse-chimpanzeeminds-are-much-ours

Hartshorne, C., 1969, 'Divine absoluteness and divine relativity', in H.W. Richardson \& D.R. Cutler (eds.), Transcendence, pp. 164-171, Beacon, Boston.

Hartshorne, C., 1978, The divine relativity: A social conception of God, Yale University Press, New Haven, CT.

Hefner, P., 1993, The human factor: Evolution, culture, and religion, Fortress Press, Minneapolis.

Hernandez-Aguilar, R.A., Moore, J. \& Pickering, T.R., 2007, 'Savanna chimpanzees use tools to harvest the underground storage organs of plants', Proceedings of the National Academy of Sciences USA 104, 19210-19213. http://dx.doi.org/10.1073/ National Academy
pnas.0707929104

Hess, E., 2008, Nim Chimpsky: The chimp who would be human, Bantam Books, New York.

Howell, N.R., 2006, 'Relations between Homo sapiens and other animals: Scientific and religious arguments', in P. Clayton \& Z. Simpson (eds.), The Oxford handbook of religion and science, pp. 945-961, Oxford University Press, Oxford. http:// of religion and science, pp. 945-961, Oxford University
dx.doi.org/10.1093/oxfordhb/9780199279272.003.0056

Joh, W.A., 2006, Heart of the cross: A postcolonial Christology, Westminster John Knox, Louisville, KY.

Kanzi the toolmaker, viewed 28 June 2015, from http://www.youtube.com/watch?v= 1zsSH9UUQtQ\&feature=share\&list=PL39720F7F0DAC9257\&index $=1$

Keller, C., 2008, On the mystery: Discerning divinity in process, Fortress, Minneapolis.

King, B.J., 2004, The dynamic dance: Nonvocal communication in African great apes, Harvard University Press, Cambridge.
King, B.J., 2007, Evolving god: A provocative view on the origins of religion, Doubleday, New York.

McFague, S., 1993, The body of God: An ecological theology, Fortress Press, Minneapolis.

New Scientist TV, Best videos of 2012: Bonobo genius makes stone tools, viewed 28 June 2015, from http://www.newscientist.com/blogs/nstv/2012/12/best-of2012-bonobo-genius-makes-primitive-tools.html

Patterson, F. \& Linden, E., 1981, The education of Koko, Holt, Rinehart \& Winston, Austin, TX.

Pruetz, J. \& Bertolani, P., 2007, 'Savanna chimpanzees, Pan troglodytes verus, hunt with tools', Current Biology 17, 412-417. http://dx.doi.org/10.1016/j.cub.2006.12.042

Prüfer, K., Munch, K., Hellmann, I., Akagi, K., Miller, J.R., Walenz, B. et al., 2012, 'The bonobo genome compared with the chimpanzee and human genomes', Nature $486,527-531$

Roffman, I. \& Nevo, E., 2010, 'Can chimpanzee biology highlight human origin and evolution?', Rambam Maimonides Medical Journal 1(1), e0009, viewed 28 June 2015, from http://www.rmmj.org.il

Russell, R.J., 2000, 'What are extraterrestrials really like?', in R. Stannard (ed.), God for the $21^{\text {st }}$ century, pp. 64-66, Templeton Foundation Press, Philadelphia.

Savage-Rumbaugh, S. \& Lewin, R., 1994, Kanzi: The ape at the brink of the human mind, John Wiley \& Sons, New York.

Savage-Rumbaugh, S., Fields, W.M. \& Spircu, T., 2004, 'The emergence of knapping and vocal expression embedded in a Pan/Homo culture', Biology and Philosophy 19, 541-575. http://dx.doi.org/10.1007/sBIPH-004-0528-0

Sugiyama, Y., 1995, 'Tool-use for catching ants by chimpanzees at Bossou and Monts Nimba, West Africa', Primates 36, 193-205. http://dx.doi.org/10.1007/ BF02381345

Uddin, M., Wildman, D.E., Wildman, L., Guozhen, X., Wenbo, J., Robert, M. et al., 2004, 'Sister grouping of chimpanzees and humans as revealed by genomewide phylogenetic analysis of brain gene expression profiles', Proceedings of the National Academy of Sciences USA 101, 2957-2962. http://dx.doi.org/10.1073/ pnas. 0308725100

Vogel, G., 1999, 'Chimps in the wild show stirrings of culture', Science 284, 2070 http://dx.doi.org/10.1126/science.284.5423.2070

Whitehead, A.N., 1978, Process and reality: Corrected edition, D.R. Griffin \& D.W. Sherburne (eds.), The Free Press, New York.

Whiten, A., Goodall, J., McGrew, W.C., Nishida, T., Reynolds, V., Sugiyama, Y. et al., 1999, 'Cultures in chimpanzees', Nature 399, 682-685. http://dx.doi.org/10.1038/ 21415

Wildman, D.E., Uddin, M., Liu, G., Grossman, L.I. \& Goodman, M., 2003, 'Implications of natural selection in shaping $99.4 \%$ nonsynonymous DNA identity between humans and chimpanzees: Enlarging genus Homo', Proceedings of the National Academy of Sciences USA 100, 7181-7188, http://www.ncbi.nlm.nih.gov/pmc/ articles/PMC165850/. http://dx.doi.org/10.1073/pnas.1232172100

Wise, S.M., 2000, Rattling the cage: Toward legal rights for animals, Da Capo Press; Perseus Books Group, Boston.

Young, P.D., 2002, 'The resurrection of the body? A feminist look at the question of transcendence', Feminist Theology 30, 41-51.

Zihlman, A.L., 1984, 'Body build and tissue composition in Pan paniscus and Pan troglodytes, with comparison to other hominoids', in R.L. Susman (ed.), The Pygmy chimpanzee, pp. 179-200, Plenum, New York. http://dx.doi.org/10.1007/978-14757-0082-4_8

Zihlman, A.L., Cronin, J.E., Cramer, D.L. \& Sarich, V.M., 1978, 'Pygmy chimpanzee as a possible prototype for the common ancestor of humans, chimpanzees and gorillas', Nature 275, 744-746. http://dx.doi.org/10.1038/275744a0 